\title{
Quality of aged meat from Charolais vs Nellore cattle
}

\section{Qualidade da carne maturada de bovines Charolês vs Nelore}

\author{
Thales de Almeida Bitencourt Cardoso ${ }^{1}$; Ana Maria Bridi2*; \\ Eder Paulo Fagan ${ }^{3}$; Marina Avena Tarsitano ${ }^{4}$; Franciele Caroline Bolfe ${ }^{1}$; \\ Louise Manha Perez ${ }^{1}$; Paulo Emílio Fernandes Prohmann ${ }^{5}$
}

\begin{abstract}
The aim of this study was evaluate the physical-chemical changes in aged meat from Charolais $\mathrm{x}$ Nellore cattle. For that, 38 male with an average weight of $437.08 \pm 15.06 \mathrm{~kg}$, were used. After 24 hours of refrigeration, the half right carcass was cut in the $13^{\mathrm{a}}$ rib to collect $35 \mathrm{~cm}$ samples from longissimus dorsi muscle. The samples were sliced, vacuum packed and aged for zero, seven and fourteen days, after the ageing time, the samples were frozen, to make analysis of exudate water loss, shear force, pressing water loss, $\mathrm{pH}$, color ( $\mathrm{L}^{*}, \mathrm{a}^{*}, \mathrm{~b}^{*}$, chroma and hue value), sensorial analysis, microbiology, and myofibrillar fragmentation index. The experimental design was completely randomized and the data were submitted to analysis of variance and the means compared by Tukey test in $5 \%$. The microbiological analysis showed that all the bacterium evaluated had their growth period until the aged day seven, and decreased to the aged day 14. The $\mathrm{pH}$ decreased with the increasing of time. The water loss and myofibrillar fragmentation index weren't affected by the ageing period. Shear force and color components $\left(L^{*}, a^{*}\right.$, $\mathrm{b}^{*}$ chroma and hue value) were affected by the ageing, being the 14 days the best result. The sensorial analysis has only show differences to tenderness. The aged cattle beef vacuum packed did not lose the fresh meat characteristics, however improved the tenderness.
\end{abstract}

Key words: Color, microbiology, $\mathrm{pH}$, sensory, tenderness

\section{Resumo}

Com o presente trabalho objetivou-se avaliar as alterações físico-químicas na carne maturada de bovinos Charolês x Nelore. Para isso foram utilizados 38 bovinos inteiros, abatidos com peso médio de 437,08 ( \pm $15,06 \mathrm{~kg}$ ). Após 24 horas de resfriamento, as meias carcaças direita foram seccionadas na altura da $13^{\mathrm{a}}$ costela para retirada de uma amostra de $35 \mathrm{~cm}$ do músculo longissimus dorsi (contra-filé), em sentido caudal - cranial. As amostras foram fatiadas, embaladas a vácuo e maturadas por zero, sete e quatorze dias. Após o término do período de maturação as carnes foram congeladas para posterior realização das análises de: perda de água por exsudato, força de cisalhamento, perda de água por pressão, $\mathrm{pH}$, cor (valor de $\mathrm{L}^{*}, \mathrm{a}^{*}, \mathrm{~b}^{*}$, croma e tonalidade), análise sensorial, microbiologia e índice de fragmentação miofibrilar. Todas as análises foram realizadas no Laboratório de Análise de Produtos de Origem Animal, da Universidade Estadual de Londrina. O delineamento experimental foi completamente casualizado e os dados foram submetidos à análise de variância e as médias comparadas pelo teste de Tukey a 5\%.

1 Discente(s) de Mestrado do Curso de Pós-Graduação em Ciência Animal. Universidade Estadual de Londrina, UEL, Londrina, PR. E-mail: thales.cardoso@zootecnista.com.br; franbolfe@hotmail.com

2 Prof $^{\mathrm{a}} \mathrm{Dr}^{\mathrm{a}}$. do Dept ${ }^{\mathrm{o}}$ de Zootecnia, UEL, Londrina, PR. E-mail: ambridi@uel.br

3 Prof. Dr. do Curso de Medicina Veterinária, Universidade Estadual do Norte do Paraná, UENP, Bandeirantes, PR. E-mail: fagan@uenp.edu.br

4 Discente de Doutorado do Curso de Pós-Graduação em Ciência Animal, UEL, Londrina, PR. E-mail: marina_avena@yahoo. com.br

5 Prof. Dr. do Centro Universitário de Maringá, CESUMAR, Maringá, PR. E-mail: pauloprohmann@yahoo.com.br Author for correspondence 
A Análise microbiológica revelou que todas as bactérias avaliadas tiveram crescimento até o dia sete de maturação, porém diminuíram no tempo 14 dias de maturação. $\mathrm{O}$ pH diminuiu com o aumento do período de maturação. A perda de água por pressão e o índice de fragmentação miofibrilar, não foram alterados com o tempo de maturação. A força de cisalhamento e os componentes da cor ( $\mathrm{L}^{*}, \mathrm{a}^{*}, \mathrm{~b}^{*}$, croma e tonalidade) foram influenciados pelos tempos de maturação, sendo o tempo 14 dias o melhor deles. A análise sensorial só apresentou diferença para maciez. A carne bovina maturada embalada a vácuo não perdeu suas características de carne, entretanto melhorou a maciez.

Palavras-chave: Cor, maciez, microbiologia, $\mathrm{pH}$, sensorial

\section{Introduction}

Improve on the quality of meat can obtain as result the increase in consumption, improve the products value and as consequence the maximization of profit for all the segments in meat industry (HAMILTON et al., 2002).

According Brondani et al. (2006) for the last years, having as final objective supply a market that is improving the level of exigency, there are a great number of techniques used in meat industry and beef production to increase the meat quality. One technology that can be used with this objective is the aged process.

The zebu races, that have a large diffusion in Brazil due the resistance to ectoparasites and to the tropical heat, have a tough meat due the highest calpastatin activity (O'CONNOR et al., 1997; PRINGLE et al., 1997; BIANCHINI et al., 2007), in comparison to the meat from Bos taurus taurus.

On the group of bovine races that have the origin in Europe (Bos taurus), the Charolais is the most common race in the south region of Brazil. This occurs due to the characteristics as high speed of growth and great weight on slaughter however this race also has low carcass finishing degree (VAZ et al., 2001), this last characteristic can cause losses on tenderness of meat due the shortening of sarcomeres, which is caused by the cooling process.

The ageing process on meat affect directly the shear force and improve the tenderness being one efficient alternative to solve individual variation between genetic groups and age of animals. The utilization of this technique produces one more homogeneous product for the consumer and increasing the market value (FRENCH et al., 2001; MONSÓN; SAÑUDO; SIERRA, 2004).

Aged meat can have improved the tenderness by action of calcium dependent enzymes, like calpains, that hydrolyze the proteins from $\mathrm{Z}$ and $\mathrm{M}$ lines in myofibrills. However, the animals from zebu origin have high calpastatin activity, that act having an inhibitory activity on calpains, preventing the proteolytic action during the meat ageing process (RUBENSAM; FELÍCIO; TERMIGNONI, 1998).

The objective of this study was to evaluate the physical-chemical changes in aged meat from Charolais x Nellore cattle.

\section{Material e methods}

The experimental animals were 38 male bulls, from crossing Charolais males with Nellore female. The animals were slaughtered around 18 months of age and body weight from $437.08 \mathrm{~kg} \pm 15.06$ in a commercial slaughterhouse under State Inspection Service (SIP), located in Campo Mourão, Paraná, Brazil. The pre slaughter housing was hydric diet and solid fasting during 23 hours, 12 hours before boarding, one hour of transportation and 10 hours in the rest bays on slaughterhouse. The slaughter was preceded of stunning with pneumatic penetration pistol. The bleeding was made immediate after stunning by the section of big vessels according the regulation for humane slaughter (BRASIL, 2000).

The right half carcasses were identified after the weighting process and kept in cold chamber during 24 hours on refrigeration temperature. Around 15 minutes after the slaughter were determinated 
the initial $\mathrm{pH}$ and by 24 hours after the slaughter the final $\mathrm{pH}$, the determination were made in the longissimus dorsi muscle, on the right half carcass close the $12^{\text {nd }}$ rib with a digital potentiometer, that have a penetration stylet.

After a 24 hour cooling period the half carcass were sectioned around the $13^{\text {rd }}$ rib in order to collect a sample with around $35 \mathrm{~cm}$ from the longissimus dorsi muscle, from tail to head way, to realize the analysis of water losses by exudate, shear force, water loss by pressure, $\mathrm{pH}$, color $\left(\mathrm{L}^{*}, \mathrm{a}^{*}, \mathrm{~b}^{*}\right.$, croma and hue value), sensorial analysis, microbiology and myofibrillar fragmentation index (MFI). All the analysis were made in the Laboratory of Analysis from Animal Origin Products, at Universidade Estadual de Londrina, in three different ageing times: zero, 7 and 14 days. The samples were identified and vacuum packaged by a sealing machine from SELOVAC in a flexible film with high barrier from Polifilm $\AA$, which is specific to meat ageing process. To the zero time the samples were frozen in a commercial freezer with minimal temperature around $-18^{\circ} \mathrm{C}$ immediately after packaged. The other two treatments stay under refrigeration in a temperature of $4 \pm 2{ }^{\circ} \mathrm{C}$ during 7 and 14 days, respectively, being then frozen in commercial freezer with minimal temperature of $-18^{\circ} \mathrm{C}$ for posterior analysis.

In order to realize the meatmicrobiologic analysis, a sample were aseptically weight with around $25 \mathrm{~g}$, the sample was crushed and diluted in $225 \mathrm{~mL}$ of saline peptone solution $0.1 \%$. The obtained dilution were correspondent to $10^{-1}$ dilution, starting from this were obtained the other decimal dilution until $10^{-7}$. The mesophilic, psychrotrophic and lactic bacterial account happened according the follow sequence: each sample dilution was sown with the depth technique in a "plate count agar" molten culture medium. After the agar solidification the plates were incubated on $37^{\circ} \mathrm{C}$ by 48 hours to mesophilic and lactic microorganisms and on $7^{\circ} \mathrm{C}$ by 72 hours to the psychrotrophic microorganisms. After the incubation period were realized the bacterial colony count (VANDERZAN; SPLITTSTOESSER, 1992).
The water losses by exudate was realized weighting the samples (meat + exudate + bag) after 7 and 14 days of age vacuum packaged, then subtracted from this the bag weight, having in the end the weight of the meat without the exudate. The water losses by pressure were realized only in the time 7 and 14 days of ageing. The technique used was the same descript by Barbut (1996), weighting a $2 \mathrm{~g}$ sample and placing it between two paper filters and pressed between two acrylic plates with $10 \mathrm{~kg}$ weight on top during 5 minutes. After the pressing, the sample was weight again in order to calculate the water loss.

The color was evaluated after a 40 minutes of exposition to the air in order to allow the oxygenation of the deoxymyoglobine and then measured with a portable Konica Minolta colorimeter to evaluate the components $L^{*}$ (luminosity), a* (red-green component) and $b^{*}$ (yellow-blue component) by the CIELAB (MINOLTA, 1998) system. The values of $\mathrm{a}^{*}$ and $\mathrm{b}^{*}$ were used to calculate the croma and hue value of meat. In each sample the color was measured in three different points.

To evaluate the tenderness the meat samples were cooked in a pre-heated oven, around $180^{\circ} \mathrm{C}$ until the intern temperature reach $72^{\circ} \mathrm{C}$. After the cooking process, the samples were stored by 24 hours around $4 \pm 2^{\circ} \mathrm{C}$ of temperature, following that were collected 6 cylindrical sub samples for each sample. The shear force was measured in this sub samples in a perpendicular way to the muscular fiber orientation with a Warner-Bratzler blade adapted in a Stable Mycro System TA-XT2i texturometer (WHIPPLE; KOOHMARAIE; DIKEMAN, 1990). The used speeds were $5 \mathrm{~mm} / \mathrm{s}$ on pre and posttest and $2 \mathrm{~mm} / \mathrm{s}$ on the test.

The sensorial panel was realized by a team of 10 pre-selected tasters. There was used a structured numeric scale from 1 to 9 points (1 as extreme acceptable and 9 extreme inacceptable) to the parameter of overall acceptability of sample; for the odor and juiciness of sample the scale was from 1 to 
5 (odor: 1 extreme intense and 5 no odor; juiciness: 1 no and 5 high); for the parameter tenderness the scale was from 1 to 7 ( 1 tough and 7 very tender). The samples were prepared in a pre-heated oven $\left(180^{\circ} \mathrm{C}\right)$ and cooked until the intern temperature reach $72^{\circ} \mathrm{C}$. The trained tasters received to evaluation 3 samples, one from each ageing time (ABNT, 1993).

The myofibrillar fragmentation index (MFI) was evaluated by the method from Culler et al. (1978), as follow: $4 \mathrm{~g}$ sample of the muscles were weight, free of fat and connective tissue. These samples were homogenized in Ultraturax to $9500 \mathrm{rpm}$ in 20 $\mathrm{mL}$ of buffer solution on $2^{\circ} \mathrm{C}$ by 40 seconds. After homogenized the samples were centrifuged at 3500 rpm during 15 minutes, on $2^{\circ} \mathrm{C}$ and the supernatant discarded. The precipitate was resuspended with $20 \mathrm{~mL}$ of buffer solution and the samples were centrifuged again and the supernatant discarded. Then the precipitate was resuspended with $10 \mathrm{~mL}$ of buffer solution and submitted to the vortex until the sample was homogeneous enough to be filtered in a sieve with polyethylene mesh (18 meshes) in order to remove the connective tissue. After this was add more $10 \mathrm{~mL}$ of buffer solution in order to wash the tube and help on the filtering process. The extraction was conducted in duplicate.

The experimental design was a completely randomized and the statistical analysis was realized with the statistic program SAEG (Sistema de Análises Estatísticas e Genéticas, versão 9.1). The data were submitted to ANOVA and in the presence of a significant difference the means were compared with the Tukey test at 5\%.

\section{Results and Discussion}

On the Table 1 it is possible to observe that the $\mathrm{pH}$ value decrease from time 0 to time $7(\mathrm{P}<0.05)$, and this last one is not different of the $\mathrm{pH}$ of 14 days aged meat. Maggioni (2009), evaluating bovine meat also observed a reduction on the $\mathrm{pH}$ value with the increase the storage time and assigned this to the development of lactic bacteria. This finding is similar to what was measured on this research, because the increase of ageing time in our case also provided the increase of colony forming units (CFU).

The CFU count, by square centimeter, for mesophilic, psychrotrophic and lactic bacteria (Table 1) shows an increase from time 0 to time 7 days, follows by a decrease in the 14 day aged time sample $(\mathrm{P}<0.05)$. The bacterial growth probably reach the decline stage where, according to Franco e Landgraf (2003), the cells lost the division capacity, and the cellular death become higher than the division rate therefore the number of viable cells decrease in a exponential way.

Table 1. Observed means and standard deviation of $\mathrm{pH}$, colony forming units (CFU) of mesophilic, psychrotrophic and lactic microorganisms on bovine meat aged for 0,7 and 14 days.

\begin{tabular}{ccccc}
\hline Aged period & $\mathrm{pH}$ & $\begin{array}{c}\text { Mesophilic } \\
\left(\log \mathrm{CFU} / \mathrm{cm}^{2}\right)\end{array}$ & $\begin{array}{c}\text { Psychrotrophic } \\
\left(\log \mathrm{CFU} / \mathrm{cm}^{2}\right)\end{array}$ & $\begin{array}{c}\text { Lactic } \\
\left(\log \mathrm{CFU} / \mathrm{cm}^{2}\right)\end{array}$ \\
\hline 0 & $5.95 \pm 0.18 \mathrm{a}$ & $2.20 \pm 0.30 \mathrm{c}$ & $0.33 \pm 0.52 \mathrm{c}$ & $1.75 \pm 0.52 \mathrm{c}$ \\
7 & $5.68 \pm 0.18 \mathrm{~b}$ & $5.80 \pm 0.56 \mathrm{a}$ & $5.67 \pm 1.00 \mathrm{a}$ & $6.16 \pm 0.44 \mathrm{a}$ \\
14 & $5.75 \pm 0.22 \mathrm{~b}$ & $4.53 \pm 0.93 \mathrm{~b}$ & $3.90 \pm 1.97 \mathrm{~b}$ & $3.55 \pm 1.83 \mathrm{~b}$ \\
\hline $\mathrm{CV}(\%)$ & 3.52 & 15.50 & 39.61 & 29.60 \\
\hline
\end{tabular}

$\mathrm{CV}$ - Variation coefficient. Different letters in the same column show significant statistical differences $(\mathrm{P}<0.05)$.

Source: Elaboration of the authors. 
According Duffy, Vanderlinde and Grau (1994), the critical factor on microorganism develops is $\mathrm{pH}$ and not the meat composition. The initial $\mathrm{pH}$ of meat provide an optimum environment for microorganisms, $\mathrm{pH}$ lower then 5.4 to 5.6 make easy for lactic bacteria growth, while $\mathrm{pH}$ close to 5.8 to 6.0 favors the mesophilic and psychrotrophic, as the lactic will have too much competition in order to growth (MANO; PEREIRA; FERNANDO, 2002).

For Mano Pereira e Fernando (2002) the shelf life of a product is the number of days that will be necessary to mesophilic bacteria reach a value of $10^{7} \mathrm{CFU} / \mathrm{cm}^{2}$ and for Fung et al. (1980) the meat that carries a contamination have a count of more than $7 \log$ CFU/g of mesophilic bacteria. The meat aged on this research, by 7 and 14 days, present a value between $6.0 \times 10^{4}$ e $3.2 \times 10^{4} \mathrm{CFU} / \mathrm{cm}^{2}$, this is according the official standard for meat quality to human consumption.

The variables of water loss by pressure and myofibrillar fragmentation index are showed on Table 2; there were not significant differences between the aged times. The water loss by exudate and the shear force present a significant difference between the times $(\mathrm{P}<0.05)$.

Table 2. Observed means and standard deviations for water losses by exudate, water losses by pressure, myofibrillar fragmentation index (MFI) and shear force for bovine meat aged by 0,7 and 14 days.

\begin{tabular}{ccccc}
\hline Aged days & Exudate $(\mathrm{g})$ & $\begin{array}{c}\text { Water losses pressure } \\
(\%)\end{array}$ & $\begin{array}{c}\text { Shear force } \\
(\mathrm{kgf})\end{array}$ & MFI \\
\hline 0 & $0.00 \pm 0.00 \mathrm{c}$ & - & $5.31 \pm 0.94 \mathrm{a}$ & $76.71 \pm 7.14$ \\
7 & $4.67 \pm 1.95 \mathrm{~b}$ & $28.80 \pm 3.01$ & $4.24 \pm 0.86 \mathrm{~b}$ & $76.12 \pm 5.76$ \\
14 & $5.71 \pm 1.90 \mathrm{a}$ & $28.33 \pm 3.10$ & $3.75 \pm 0.85 \mathrm{c}$ & $76.88 \pm 5.25$ \\
\hline $\mathrm{CV}(\%)$ & 37.07 & 10.70 & 19.99 & 7.97 \\
\hline
\end{tabular}

$\mathrm{CV}$ - Variation coefficient. Different letters in the same column indicate a significant statistical differences $(\mathrm{P}<0.05)$.

Source: Elaboration of the authors.

The values observed for water losses by exudate show significant difference between the day 7 and 14 of aged process, the biggest water loss was on the $14^{\text {th }}$ day according with the expected. The results obtained by Miller et al. (1996) showed that during the conditioning chilled process occurs the higher exudate loss. This is due to the great protein denaturation that contributes to increase the loss of exudate from muscular tissue (LAWRIE, 2005).

The parameter water loss by pressure does not show significant difference between the day 7 and 14 on ageing process. According to Zamora et al. (1996), the water loss reduces until 24 hours post mortem and after that stay stable. This result also is according with that found by Huidobro et al. (2003) that do not found significant difference for water loss in bovine aged meat. These authors also work with young bovines in similar conditions to that on animals evaluated by this trial.

The shear force results obtained by samples from day 0,7 and 14 of aged had significant statistical difference between them $(\mathrm{P}<0.05)$. The shear force for the 14 days samples show that the process is efficient, according to Judge et al. (1989) muscular tissue with shear force lower than $3.6 \mathrm{kgf} / \mathrm{cm}^{2}$ are considerate extremely tender. Apple et al. (2001), Zeola et al. (2007) e Maggione (2009) also found data showing that the aged process reduce the shear force.

During the ageing process happens a protein denaturation, this cause disintegration of muscular fibers affecting directly the shear force, improving the meat tenderness (FRENCH et al., 2001), the 
results find on this trial are according to that, the meat were more tender according to increase the ageing time, what means the shear force reduce with the time.

The values for the myofibrillar fragmentation index do not show statistical difference. The three ageing times had values that are correspondents to very tender meat, according to Culler et al. (1978) values close to 30 indicate tough meat; values close to 60 , tender meat and values close to 100 , very tender meat.

The values found in this trial were between 76.12 and 76.88 , this shows that the muscle already were tender before the ageing process. This is due to the experimental animals that were young and they naturally have more tender meat.
Similar results for the myofibrillar fragmentation index were found by Constantino (2010), using the ageing process for sheep meat from disposal animals and Tarsitano (2010), working with the process for swine meat. This authors found significant statistical differences $(\mathrm{P}<0.05)$ for the myofibrillar fragmentation index in different ageing times.

The results for color analysis (Table 3 ), having as parameter the luminosity $\left(\mathrm{L}^{*}\right)$, red intensity $\left(\mathrm{a}^{*}\right)$, yellow intensity $\left(b^{*}\right)$, croma $(C)$ and hue value, showed a significant statistical difference $(\mathrm{P}<0.05)$ in all the parameters on the evaluation from the different ageing times.

Table 3. Means and standard deviation for color parameter of luminosity $\left(\mathrm{L}^{*}\right)$, red intensity $\left(\mathrm{a}^{*}\right)$, yellow intensity $\left(\mathrm{b}^{*}\right)$, croma e hue value for bovine meat aged by 0,7 and 14 days.

\begin{tabular}{cccccc}
\hline Aged Days & $\mathrm{L}^{*}$ & $\mathrm{a}^{*}$ & $\mathrm{~b}^{*}$ & Croma & Hue value $\left(^{\circ}\right)$ \\
\hline 0 & $36.57 \pm 2.46 \mathrm{ab}$ & $14.41 \pm 1.87 \mathrm{~b}$ & $7.63 \pm 1.28 \mathrm{~b}$ & $16.33 \pm 2.14 \mathrm{~b}$ & $33.73 \pm 5.03 \mathrm{~b}$ \\
7 & $37.46 \pm 3.38 \mathrm{a}$ & $16.71 \pm 2.65 \mathrm{a}$ & $9.79 \pm 2.31 \mathrm{a}$ & $19.40 \pm 3.34 \mathrm{a}$ & $37.91 \pm 6.50 \mathrm{~b}$ \\
14 & $35.11 \pm 2.78 \mathrm{~b}$ & $12.97 \pm 1.93 \mathrm{c}$ & $10.55 \pm 1.88 \mathrm{a}$ & $16.74 \pm 2.53 \mathrm{~b}$ & $61.86 \pm 12.40^{\mathrm{a}}$ \\
\hline $\mathrm{CV}(\%)$ & 7.97 & 14.82 & 20.07 & 15.54 & 19.31 \\
\hline
\end{tabular}

$\mathrm{CV}$ - Variation coefficient. Different letter in the same column indicate significant statistical differences $(\mathrm{P}<0.05)$.

Source: Elaboration of the authors.

Comparing the luminosity between the meat from time 0 and meat from time 7 and 14 there is not significant statistical difference, however when comparing the meat from time 7 and the meat from time 14 there was a decreasing on the $\mathrm{L}^{*}(\mathrm{P}<0.05)$, what means that the meat was more dark. The muscular fibers with high $\mathrm{pH}$ become distended on the meat environment, and forming a barrier to oxygen diffusion and to light absorption, what means that the meat become more dark (SILVA SOBRINHO et al., 2005).

According to Maganhini et al. (2007), there was a negative correlation between the luminosity ( $\mathrm{L}^{*}$ ) and $\mathrm{pH}$ of meat, what is similar to the result found in this trial. These two variables had the exactly opposite behavior, as the $\mathrm{pH}$ turn low, the $\mathrm{L}^{*}$ value turn high, and according the increasing of $\mathrm{pH}$ values the $\mathrm{L}^{*}$ value turn low.

The red intensity $\left(\mathrm{a}^{*}\right)$ increase from time 0 (14.41) to time 7 (16.71) from ageing, this result can be related to the low respiratory mitochondrial activity on meat. According increase the oxygen on cut surface, start forming the oxymyoglobin that have the bright red color (O'KEEFE; HOOD, 1981).

The $\mathrm{a}^{*}$ variable is connected also to the myoglobin content in muscular tissue, according increase the time this protein can be extravasated with the meat exudate during the storage time (Table $2)$, reducing the red color intensity. 
Another factor that can influence the low a* value is the chemical changes on myoglobin pigment. The increase of storage time, the iron's pigment has tendency to oxidize and form the metamyoglobin, which have a brown color in contraposition to the bright red from oxymyoglobin (LAWRIE, 2005).

The $\mathrm{a}^{*}$ value found on the present trial are below those described to Purchas (1988), that are between 18 and 22, however, Ribeiro et al. (2002) also working with crossed animals observed values around 14.5 e 15.3, that are more similar to what are found in this experiment.

The yellow intensity $\left(b^{*}\right)$ turn high according increase the ageing time. At aged time 0, showed the low intensity (7.63) when compared to meats on time 7 (9.79) and 14 (10.55) days of ageing process, the trial develop by Mancini e Hunt (2005), show a similar result and according these authors the increase on yellow intensity can be attributed to the fact of the heme pigment be more sensitive to the oxidation.

In other trial, Abularach, Rocha and Felício (1998) describe the yellow intensity of 3.40 as low and when was higher than 8.28 as high. So, that can be considerate that on aged times 7 and 14 days the yellow intensity was high.
The meat croma (saturation) is an indicative of color purity, what means how different from gray, this parameter is calculated from the results of $a^{*}$ and $b^{*}$ measures. This parameter increase from time 0 to 7 , and reduce from time 7 to 14 , reproducing the behavior from the $a^{*}$ variable. The hue value characteristic also is calculated in function of the $a^{*}$ and $b^{*}$ value and increase according the time of storage of meat, the same behavior was observed for the $b^{*}$ parameter.

The measures related with odor intensity, juiciness and overall acceptability are presented on the Table 4, there was not significant statistical difference $(\mathrm{P}>0.05)$ between the three different ageing times. In relation to the odor parameter this result is interesting because the consumers complain about the characteristic odor of ageing process, and on the present trial this was not observed.

Even having a result for larger water loss by exudate on the samples aged by 14 days (Table 2), there were not significant statistical differences on juiciness (Table 4). For the tenderness parameters the tasters on the sensorial panel preferred as being more tender the meat samples aged by 7 and 14 days.

Table 4. Observed means and standard deviations for the parameter odor intensity, juiciness, tenderness and overall acceptability on the sensorial analysis panel for bovine meat aged by 0,7 and 14 days.

\begin{tabular}{ccccc}
\hline Aged Days & Odor intensity & Juiciness & Tenderness & Overall acceptability \\
\hline 0 & $2.70 \pm 1.06$ & $3.10 \pm 0.57$ & $3.60 \pm 0.84 \mathrm{~b}$ & $5.70 \pm 1.25$ \\
7 & $2.70 \pm 0.82$ & $3.60 \pm 1.07$ & $5.00 \pm 0.94 \mathrm{a}$ & $6.80 \pm 1.13$ \\
14 & $2.80 \pm 1.03$ & $3.50 \pm 0.97$ & $4.70 \pm 1.06 \mathrm{a}$ & $6.60 \pm 1.07$ \\
\hline CV $(\%)$ & 35.76 & 26.43 & 21.49 & 18.16 \\
\hline
\end{tabular}

$\mathrm{CV}$ - Variation coefficient. Different letters in the same column indicate significant statistical differences.

Source: Elaboration of the authors. 


\section{Conclusion}

The bovine aged meat vacuum packaged do not lost the meat characteristics, however increase the tenderness. The aged period with best results was 7 days, because the quality parameters do not show significant statistical differences between 7 and 14 days and reducing the meat storage time will be possible to save money for the industry.

\section{References}

ASSOCIAÇÃO BRASILEIRA DE NORMAS TÉCNICAS - ABNT. NBR 12806: análise sensorial de alimentos e bebidas. Rio de Janeiro: ABNT, 1993.

ABULARACH, M. L. S.; ROCHA, C. E.; FELÍCIO, P. E. Características de qualidade do contrafilé (m. L. dorsi) de touros jovens da raça Nelore. Ciência e Tecnologia de Alimentos, Campinas, v. 18, n. 2, p. 205-210, 1998.

APPLE, J. K.; DAVIS, J. R.; RAKES, L. K.; MAXWELL, C. V.; STIVARIUS, M. R.; POHLMAN, F. W. Effects of dietary magnesium and duration of refrigerated storage on the quality of vacuum-packaged, boneless pork loins. Meat Science, Champaign, v. 57, n. 1, p. 43-53, 2001.

BARBUT, S. Estimates and detection of the PSE problem in young turkey breast meat. Canadian Journal of Animal Science, Ottawa, v. 76, n. 3, p. 455-457, 1996.

BIANCHINI, W.; SILVEIRA, A. C.; JORGE, A. M.; ARRIGONI, M. B.; MARTINS, C. L.; RODRIGUES, E.; HADLICH, J. C.; ANDRIGHETTO, C. Efeito do grupo genético sobre as características de carcaça e maciez da carne fresca e maturada de bovinos superprecoces. Revista Brasileira de Zootecnia, Viçosa, v. 36, n. 6, p. 2109-2117, 2007.

BRASIL, Ministério da Agricultura Pecuária e Abastecimento. Instrução normativa n. 3, de 17 de Janeiro de 2000. seção, p.-X-.

BRONDANI, I. L.; SAMPAIO, A. A. M.; RESTLE, J.; ALVES FILHO, D. C.; FREITAS, L. S.; DO AMARAL, G. A.; SILVEIRA, M. F.; CEZIMBRA, I. M. Composição física da carcaça e aspectos qualitativos da carne de bovinos de diferentes raças alimentados com diferentes níveis de energia. Revista Brasileira de Zootecnia, Viçosa, v. 35, n. 5, p. 2034-2042, 2006.

CONSTANTINO, C. Desempenho, características da carcaça e da carne maturada de ovelhas suplementadas com magnésio. 2010. Dissertação (Mestrado em Ciência Animal) - Universidade Estadual de Londrina, Londrina.
CULLER, R. D.; PARRISH JUNIOR; F. C.; SMITH, G. C.; CROSS, H. R. Relationship of myofibril fragmentation index to certain chemical, physical and sensory characteristic of bovine longissimus muscle. Journal of Food Science, Chicago, v. 43, n. 4, p. 11771180, 1978.

DUFFY, L. L.; VANDERLINDE, P. B.; GRAU, F. $\mathrm{H}$. Growth of Listeria monocytogenes on vacuumpacked cooked effects of $\mathrm{pH}, \mathrm{a}_{\mathrm{w}}$, nitrite and ascorbate. International Journal of Food Microbiology, Cambridge, v. 23, n. 3-4, p. 377-390, 1994.

FRANCO, B. D. G. de M.; LANDGRAF, M. Microrganismos patogênicos de importância em alimentos. In: FRANCO, B. D. G. de M.; LANDGRAF, M. Microbiologia dos alimentos. São Paulo: Ed. Atheneu, 2003. p. 55-60.

FRENCH, P.; O'RIORDAN, E. G. O.; MONAHAN, F. J.; CAFFREY, P. J.; MOONEY, M. T.; TROY, D. J.; MOLONEY, A.P. The eating quality of meat from steers fed grass and/or concentrates. Meat Science, Champaign, v. 57, n. 4, p. 379-386, 2001.

FUNG, D. Y. C.; KASTNER, C. L.; HUNT, M. C.; DIKEMAN, M. E.; KROPF, D. H. Mesophilic and psychrotrophic bacteria population on hot-boned and conventionally processed beef. Journal of Food Protection, Des Moines, v. 43, p. 547-550, 1980.

HAMILTON, D. N.; ELLIS, M.; HEMANN, M. D.; MCKEITH, F. K.; MILLER, K. D.; PURSER, K. W. The impact of Longissmus glycolytic potential and shortterm feeding of magnesium sulfate heptahydrate prior to slaughter on carcass characteristics and pork quality. Journal of Animal Science, Champaign, v. 80, n. 6, p. 1586-1592, 2002.

HUIDOBRO, F. R.; MIGUEL, E.; ONEGA, E.; BLÁZQUEZ, B. Changes in meat quality characteristics of bovine meat during the first 6 days post-mortem. Meat Science, Champaign, v. 65, n. 4, p. 1439-1446, 2003.

JUDGE, M. D.; ABERLE, E. D.; FORREST, J. C.; MERKEL, R. A. Principles of meat science. 2. ed. Iowa: Kendall Hunt. 1989.

LAWRIE, R. A. Ciência da carne. Porto Alegre: Artmed Editora, 2005.

MAGANHINI, M. B.; MARIANO, B.; SOARES, A. L.; GUARNIERI, P. D.; SHIMOKOMAKI, M.; IDA, E. I. Carnes PSE (Pale, Soft, Exudative) e DFD (Dark, Firm, Dry) em lombo suíno numa linha de abate industrial. Ciência e Tecnologia de Alimentos, Campinas, v. 27, n. 1, p. 69-72, 2007. 
MAGGIONE, D. Produção e qualidade da carne de bovinos cruzados (Bos taurus taurus vs. Bos taurus indicus) submetidos a duas dietas e abatidos com dois graus de acabamento. 2009. Tese (Doutorado em Zootecnia) - Universidade Estadual de Maringá, Maringá.

MANCINI, R. A.; HUNT, M. C. Review: current research in meat color. Meat Science, Champaign, v. 71, n. 1, p. 100-121, 2005.

MANO, S. B.; PEREIRA, J. A. O.; FERNANDO, G. D. G. Aumento da vida útil e microbiologia da carne suína embalada em atmosfera modificada. Ciência e Tecnologia de Alimentos, Campinas, v. 22, n. 1, p. 1-10, 2002.

MILLER M. F.; CARR, M. A.; SCHLUTER, A. R.; JONES, D. K.; MEADE, M. K.; RAMSEY, C. B. Distribution packaging method and storage time on microbiological characteristics and incidence of the pathogens Listeria monocygenes and Salmonella in pork. Journal of Food Quality, Ames, v. 19, n. 5, p .413-422, 1996.

MINOLTA. Precise color communication - color control from perception to instrumentation. Japan: Minolta Co., Ltd. 1998.

MONSÓN, F.; SAÑUDO, C.; SIERRA, I. Influence of cattle breed and ageing time on textural meat quality. Meat Science, Champaign, v. 68, n. 4, p. 595-602, 2004.

O'CONNOR, S. F.; TATUM, J. D.; WULF, D. M.; GREEN, R. D.; SMITH, G. C. Genetic effects on beef tenderness in Bos indicus composite and Bos taurus cattle. Journal of Animal Science, Champaign, v. 75, n. 7, p. 1822-1830, 1997.

O'KEEFE, M.; HOOD, D. E. Anoxic storage of fresh beef. 2: color stability and weight loss. Meat Science, Champaign, v. 5, n. 4, p. 267-281, 1981.

PRINGLE, T. D.; WILLIAMS, S. E.; LAMB, B. S.; JOHNSON, D. D.; WEST, R. L. Carcass characteristics, the calpain proteinase system, and aged tenderness of Angus and Brahman crossbred steers. Journal of Animal Science, Champaign, v. 75, n. 7, p. 2955-2961, 1997.

PURCHAS, R. W. Some experiences with dark-cuting beef in New Zealand. In: AUSTRALIAN WORKSHOP. AUSTRALIAN MEAT AND LIVE-STOCK RESEARCH AND DEVELOPMENT CORPORATION, 1988, Sydney. Anais... Sydney: [s. n], 1988. p. 42-51.
RIBEIRO, F. G.; LEME, P. R.; BULLE, M. L. M.; LIMA, C. G.; SILVA, S. L.; PEREIRA, A. S. C.; LANNA, D. P. D. Características da carcaça e qualidade da carne de tourinhos alimentados com dietas de alta energia. Revista Brasileira de Zootecnia, Viçosa, v. 31, n. 2, p. 749-756, 2002.

RUBENSAM, J. M.; FELÍCIO, P. E.; TERMIGNONI, C. Influência do genótipo bos indicus na atividade de calpastatina e na textura da carne de novilhos abatidos no Sul do Brasil. Ciência Tecnologia de Alimentos, Campinas, v. 18, n. 4, p. 405-409, 1998.

SILVA SOBRINHO, A. G.; PURCHAS, R. W.; KADIM, I. T.; YAMAMOTO, S. M. Características de qualidade da carne de ovinos de diferentes genótipos e idades ao abate. Revista Brasileira de Zootecnia, Viçosa, v. 34, n. 3, p. 1070-1078, 2005.

TARSITANO, M. A. Efeito da suplementação dietética com magnésio e da maturação sobre a qualidade da carne suína. 2010. Dissertação (Mestrado em Ciência Animal) - Universidade Estadual de Londrina, Londrina.

VANDERZAN, C.; SPLITTSTOESSER, D. F. Compendium of methods for the microbiological examination of foods. $3^{\text {th }}$ ed. Washington: APHA, 1992.

VAZ, F. N.; RESTLE, J.; FEIJÓ, G. L. D.; BRONDANI, I. L.; ROSA, J. R. P.; SANTOS, A. P. Qualidade e composição química da carne de bovinos de corte inteiros ou castrados de diferentes grupos genéticos Charolês $\mathrm{x}$ Nelore. Revista Brasileira de Zootecnia, Viçosa, v. 30, n. 2, p. 518-525, 2001.

WHIPPLE, G.; KOOHMARAIE, M.; DIKEMAN, M. E. Evaluation of attributes that affect longissimus muscle tenderness in bos taurus and bos indicus cattle. Journal Animal Science, Champaign, v. 68, n. 9, p. 2716-2728, 1990.

ZAMORA, F.; DEBITON, E.; LEPETIT, J.; LEERT, A.; DRANSFIELD, E.; OUALI, A. Predicting variability of ageing and toughness in beef $\mathrm{M}$. Longissimus lumborun et thoracis. Meat Science, Champaign, v. 43, n. 3-4, p. 321-333, 1996.

ZEOLA, N. M. B. L.; SOUZA, P. A.; SOUZA, H. B. A.; SILVA SOBRINHO, A. G. Parâmetros qualitativos da carne ovina: um enfoque à maturação e marinação. Revista Portuguesa de Ciências Veterinárias, Lisboa, v. 102, n. 563, p. 215-224, 2007. 
